\title{
Psychrobacter lutiphocae sp. nov., isolated from the faeces of a seal
}

Correspondence

A. F. Yassin

yassin@mibi03.meb.uni-bonn.de

\author{
A. F. Yassin ${ }^{1}$ and H.-J. Busse ${ }^{2}$ \\ ${ }^{1}$ Institut für Medizinische Mikrobiologie und Immunologie der Universität Bonn, Sigmund-Freud- \\ Straße 25, 53127 Bonn, Germany \\ ${ }^{2}$ Institut für Bakteriologie, Mykologie und Hygiene, Veterinärmedizinische Universität Wien, \\ A-1210 Wien, Austria
}

The taxonomic status of a Gram-negative-staining bacterium, isolated from the faeces of a seal, was investigated using a polyphasic approach. Comparative 16S rRNA gene sequence analysis showed that the novel isolate formed a distinct phyletic line within the genus Psychrobacter, displaying $>3.3 \%$ sequence divergence with other known Psychrobacter species. The generic assignment was confirmed by chemotaxonomic data, which revealed a fatty acid profile that included straight-chain saturated, unsaturated and 3-hydroxylated fatty acids, with $\mathrm{C}_{18: 1} \omega 9 c$ as the major fatty acid. A ubiquinone with eight isoprene units $(\mathrm{Q}-8)$ was the predominant respiratory quinone and spermidine was the predominant polyamine. The novel isolate was distinguished from other members of the genus Psychrobacter by using a set of phenotypic properties. On the basis of phenotypic and phylogenetic considerations, it is proposed that the new isolate represents a novel species, for which the name Psychrobacter lutiphocae sp. nov. is proposed. Strain IMMIB $\mathrm{L}-1110^{\top}$ (=DSM $21542^{\top}=$ CCUG $56590^{\top}$ ) is the type strain.

The genus Psychrobacter was first described by Juni \& Heym (1986) to comprise psychrophilic and psychrotolerant, halotolerant, aerobic, non-motile, Gram-negative coccobacilli. Members of the genus Psychrobacter are capable of growing at temperatures ranging from -10 to $37^{\circ} \mathrm{C}$ and they vary from strict (stenothermal) psychrophiles, e.g. Psychrobacter frigidicola $\left(0-22{ }^{\circ} \mathrm{C}\right)$, to eurythermal psychrophiles, e.g. Psychrobacter okhotskensis (-5$35{ }^{\circ} \mathrm{C}$ ). At the time of writing, the genus comprised 29 species, which have been isolated from a variety of lowtemperature marine environments (Romanenko et al., 2002, 2004), Antarctic sea ice (Bowman et al., 1997; Bozal et al., 2003; Shivaji et al., 2005; Heuchert et al., 2004), ornithogenic soil and sediments (Bowman et al., 1996), the stomach contents of the Antarctic krill, Euphausia superba (Denner et al., 2001), seawater (north-western Pacific Ocean, $300 \mathrm{~m}$ depth), the deep sea (Maruyama et al., 2000) and the internal tissues of a marine ascidian. Other sources of Psychrobacter include pigeon faeces (Kämpfer et al., 2002), fish, poultry, dairy products and fermented seafood (Yoon et al., 2003, 2005b; Jung et al., 2005), clinical sources and an infected lamb (Vela et al., 2003). During the

The GenBank/EMBL/DDBJ accession number for the $16 \mathrm{~S}$ rRNA gene sequence of strain IMMIB L-1110 is FM165580.

Supplementary tables of phenotypic characteristics and cellular fatty acid compositions of strain IMMIB $L-1110^{\top}$ and other recognized species of the genus Psychrobacter are available with the online version of this paper. characterization of bacterial isolates from clinical sources, we encountered a Gram-negative-staining, oxidase-positive, non-motile, coccoid bacterium, which had been isolated from the faeces of a seal. In this paper, we report on the taxonomic characterization of this isolate, designated strain IMMIB L-1110 ${ }^{\mathrm{T}}$, by using a polyphasic approach. Based on the results of this study, we describe a novel species, Psychrobacter lutiphocae sp. nov.

Strain IMMIB L- $1110^{\mathrm{T}}$ was isolated from the faeces of a seal. The strain was grown aerobically at $37^{\circ} \mathrm{C}$ on Columbia agar (Oxoid) supplemented with $5 \%$ sheep blood. It was characterized biochemically using the API 20NE, API Coryne, API 20 Strep and API ZYM systems (bioMérieux), according to the manufacturer's instructions. Hydrolysis of casein, elastin, guanine, xanthine, hypoxanthine, tyrosine and uric acid was investigated by using previously described methods (Gordon, 1966, 1967; Gordon \& Mihm, 1957). To determine the chemotaxonomic characteristics of strain IMMIB L-1110 ${ }^{\mathrm{T}}$, the organism was cultivated in shake flasks containing BHI broth for 1 week at $37^{\circ} \mathrm{C}$. After checking for purity at maximum growth, the organism was killed with formaldehyde $(1 \%, v / v)$, harvested by centrifugation, washed with distilled water and freeze-dried. Fatty acids were analysed as described previously (Yassin et al., 2007). Polar lipids were determined using TLC as described previously (Yassin et al., 1993). Respiratory quinones were extracted and purified according to Collins et al. (1977). Mass spectral 
analyses of the quinones were recorded in positive-ion mode on a Q-TOF 2 mass spectrometer (Micromass) equipped with a nanospray source as described by Yassin \& Hupfer (2006). Biomass to be subjected to polyamine analysis was grown on $\mathrm{BHI}$ broth and harvested at the lateexponential growth phase. Extraction of polyamines was performed as described by Busse \& Auling (1988) and analysis was done using the HPLC equipment described by Stolz et al. (2007).

For phylogenetic analysis, the 16S rRNA gene sequence of strain IMMIB L-1110 ${ }^{\mathrm{T}}$ was amplified by PCR using procedures described by Rainey et al. (1996) and directly sequenced using a Taq Dye-deoxy Terminator Cycle Sequencing Kit (Applied Biosystems) and an automatic DNA sequencer (model 310; Applied Biosystems). The closest relatives of the isolate were determined by searching the GenBank database. The 16S rRNA gene sequence of isolate IMMIB L- $1110^{\mathrm{T}}$ and the retrieved sequences were added to the ARB database (Ludwig et al., 2004) and aligned using the respective tool of the ARB package. Phylogenetic trees were reconstructed with neighbour-joining (Saitou \& Nei, 1987), maximum-parsimony (Fitch, 1971) and maximum-likelihood (Felsenstein, 1981) methods. The stability of the groupings was estimated by bootstrap analysis (Felsenstein, 1985) of the neighbour-joining method based on 1000 replications.

Strain IMMIB L- $1110^{\mathrm{T}}$ was examined for a range of phenotypic characteristics. The isolate formed non-pigmented, circular, smooth, opaque colonies with a diameter of $\sim 2 \mathrm{~mm}$ when grown on Columbia blood agar. Cells were non-motile, Gram-negative-staining, diploid coccobacilli. The organism grew aerobically and was catalaseand oxidase-positive. The growth temperature range of the isolate was $10-37^{\circ} \mathrm{C}$. Although $\mathrm{NaCl}$ was not required for growth, strain IMMIB L- $1110^{\mathrm{T}}$ grew in the presence of $6 \%$ $\mathrm{NaCl}$. Strain IMMIB L-1110 ${ }^{\mathrm{T}}$ was able to assimilate and hydrolyse a set of organic substrates. The detailed phenotypic characteristics of strain IMMIB L $-1110^{\mathrm{T}}$ are given in the species description and Table 1. Supplementary Table S1 (available in IJSEM Online) shows the phenotypic characteristics of strain IMMIB L-1110 compared with those of most of the recognized species of the genus Psychrobacter.

Chemotaxonomically, strain IMMIB L-1110 ${ }^{\mathrm{T}}$ possessed chemical markers that supported its assignment to the genus Psychrobacter. Cellular fatty acid analysis revealed the presence of straight-chain saturated fatty acids $\mathrm{C}_{16: 0}$ $(1.7 \%), \mathrm{C}_{17: 0}(1.9 \%)$ and $\mathrm{C}_{18: 0}(3.7 \%)$, mono-unsaturated fatty acids $\mathrm{C}_{16: 1} \omega 7 c(8.3 \%), \mathrm{C}_{17: 1} \omega 8 c(2.6 \%)$, $\mathrm{C}_{18: 1} \omega 9 c(69.3 \%), \mathrm{C}_{18: 1} 9 t / 11 c(4.7 \%)$ and $\mathrm{C}_{19: 1}(0.8 \%)$ and the 3-hydroxylated fatty acid $\mathrm{C}_{12: 0} 3-\mathrm{OH}(5.5 \%)$. The detailed fatty acid profile of strain IMMIB L-1110 $0^{\mathrm{T}}$ and those of most of the recognizes species of the genus Psychrobacter are shown in Supplementary Table S2. Strain IMMIB L- $1110^{\mathrm{T}}$ contained diphosphatidylglycerol, phosphatidylglycerol and phosphatidylethanolamine as the
Table 1. Phenotypic characteristics of strain IMMIB L-1110 and the phylogenetically most closely related Psychrobacter species

Strains: 1, Psychrobacter lutiphocae sp. nov. IMMIB L-1110 ${ }^{\mathrm{T}}$ (data from this study); 2, P. celer KCTC $12313^{\mathrm{T}}$ (Yoon et al., 2005a); 3, P. arenosus KMM $3659^{\mathrm{T}}$ (Romanenko et al., 2004); 4, P. pacificensis IFO $16270^{\mathrm{T}}$ (Maruyama et al., 2000); 5, P. marincola DSM $14160^{\mathrm{T}}$ (Romanenko et al., 2002); 6, P. submarinus DSM $14161^{\mathrm{T}}$ (Romanenko et al., 2002); 7, P. faecalis DSM $14664^{\mathrm{T}}$ (Kämpfer et al., 2002); 8, P. pulmonis S-606 ${ }^{\mathrm{T}}$ (Vela et al., 2003). All strains are negative for assimilation of maltose, D-mannose and D-mannitol, for acid production from maltose, D-mannitol, D-sorbitol, sucrose and trehalose and for arginine dihydrolase activity. +, Positive; negative; W, weak; ND, no data available.

\begin{tabular}{|c|c|c|c|c|c|c|c|c|}
\hline Characteristic & 1 & 2 & 3 & 4 & 5 & 6 & 7 & 8 \\
\hline Nitrate reduction & + & - & + & - & - & - & $+^{*}$ & + \\
\hline \multicolumn{9}{|l|}{ Assimilation of: } \\
\hline $\mathrm{N}$-Acetylglucosamine & - & ND & - & - & - & - & + & - \\
\hline Adipic acid & - & ND & $\mathrm{ND}$ & - & - & - & - & - \\
\hline L-Arabinose & - & - & + & - & - & - & $\mathrm{w}$ & - \\
\hline Capric acid & - & $\mathrm{ND}$ & - & - & - & - & $\mathrm{ND}$ & - \\
\hline Citrate & - & - & + & - & - & - & + & - \\
\hline Gluconate & - & ND & - & - & - & - & - & - \\
\hline D-Glucose & - & - & - & - & - & - & $\mathrm{W}$ & - \\
\hline Malate & + & + & + & + & - & - & + & - \\
\hline Phenylacetic acid & - & ND & - & - & - & - & - & - \\
\hline \multicolumn{9}{|l|}{ Acid production from: } \\
\hline L-Arabinose & - & + & + & $-*$ & - & + & - & - \\
\hline D-Glucose & - & + & + & $-*$ & - & - & - & - \\
\hline Lactose & - & + & + & $-^{\star}$ & $-^{\star}$ & $-{ }^{\star}$ & - & - \\
\hline Raffinose & - & - & - & $-{ }^{*}$ & $-{ }^{*}$ & $-*$ & - & ND \\
\hline D-Xylose & - & + & - & $-{ }^{\star}$ & - & - & - & - \\
\hline \multicolumn{9}{|l|}{ Enzyme activities: } \\
\hline Acid phosphatase & - & - & $\mathrm{ND}$ & $+^{*}$ & $+^{*}$ & $-{ }^{\star}$ & $\mathrm{ND}$ & - \\
\hline Alkaline phosphatase & - & + & ND & $+^{*}$ & $+^{*}$ & $+^{*}$ & $\mathrm{ND}$ & - \\
\hline Cysteine arylamidase & - & - & ND & $+^{*}$ & $+^{*}$ & $+^{*}$ & ND & + \\
\hline Ester lipase (C8) & + & + & ND & $+^{*}$ & $+^{*}$ & $+^{*}$ & ND & + \\
\hline Esterase (C4) & - & + & ND & $+^{*}$ & $+^{*}$ & $+^{*}$ & ND & + \\
\hline$\beta$-Galactosidase & - & - & ND & $-^{*}$ & $-{ }^{*}$ & $-*$ & ND & - \\
\hline Leucine arylamidase & + & + & ND & $t^{*}$ & $+^{*}$ & ND & ND & + \\
\hline Lipase (C14) & - & - & ND & $-{ }^{*}$ & $-{ }^{*}$ & $-*$ & $\mathrm{ND}$ & - \\
\hline $\begin{array}{l}\text { Naphthol-AS-BI- } \\
\text { phosphohydrolase }\end{array}$ & + & - & ND & $+^{*}$ & $+^{*}$ & $\mathrm{ND}$ & $\mathrm{ND}$ & - \\
\hline Urease & + & - & - & + & - & - & - & - \\
\hline Valine arylamidase & - & - & ND & $+^{*}$ & $+^{*}$ & $+^{*}$ & $\mathrm{ND}$ & + \\
\hline
\end{tabular}

${ }^{\star}$ Data from Bakermans et al. (2006).

characteristic polar lipids. Mass spectral analysis of the main isoprenoid component from strain IMMIB L-1110 ${ }^{\mathrm{T}}$ showed a strong peak at $m / z 727.49$ that was attributable to $[\mathrm{M}+\mathrm{H}]^{+}$in the high mass region. This corresponds to a ubiquinone with eight isoprene units (Q-8). The polyamine pattern of strain IMMIB L-1110 ${ }^{\mathrm{T}}$ consisted of ( $\mu \mathrm{mol} \mathrm{g}{ }^{-1}$ dry weight) spermidine (45.9) and minor-totrace amounts of putrescine (3.7), spermine (1.3), 
cadaverine (1.2), sym-homospermidine (0.3) and 1,3diaminpropane $(0.1)$. The polyamine pattern was in excellent agreement with those of other Psychrobacter species, including Psychrobacter pacificensis and Psychrobacter celer (Hamana et al., 2007).

To establish the phylogenetic position of strain IMMIB $\mathrm{L}-1110^{\mathrm{T}}$, its $16 \mathrm{~S}$ rRNA gene sequence was determined in this study (1502 bases). Sequence database searches revealed that strain IMMIB L-1110 ${ }^{\mathrm{T}}$ was most closely related to species of the genus Psychrobacter (data not shown). Phylogenetic analysis confirmed the association of strain IMMIB L-1110 with the genus Psychrobacter. A tree was constructed using the neighbour-joining method to show the phylogenetic position of strain IMMIB L-1110 ${ }^{\mathrm{T}}$ (Fig. 1). Strain IMMIB L-1110 formed a distinct subline within the genus Psychrobacter, which was associated with a subcluster containing $P$. celer SW- $238^{\mathrm{T}}$, P. arenosus DSM $15389^{\mathrm{T}}$ and $P$. pacificensis IFO
$16270^{\mathrm{T}}$. The association of strain IMMIB L- $1110^{\mathrm{T}}$ with these strains was not statistically significant, as evident from the bootstrap resampling results. Pairwise sequence comparisons to these species revealed similarities of $96.7,96.3$ and $95.5 \%$, respectively. Other Psychrobacter species displayed substantially lower levels of similarity (data not shown). Although, there is no precise correlation between 16S rRNA gene sequence similarity and species delineation, it is generally recognized that divergence values of $3 \%$ and more are significant (Stackebrandt \& Goebel, 1994).

It is clear from this polyphasic taxonomic study that strain IMMIB L- $1110^{\mathrm{T}}$ represents a distinct species within the genus Psychrobacter. Therefore, based on both phenotypic and molecular genetic characterizations, we consider that strain IMMIB L-1110 ${ }^{\mathrm{T}}$ merits classification in a novel species of the genus Psychrobacter, for which the name Psychrobacter lutiphocae sp. nov. is proposed.

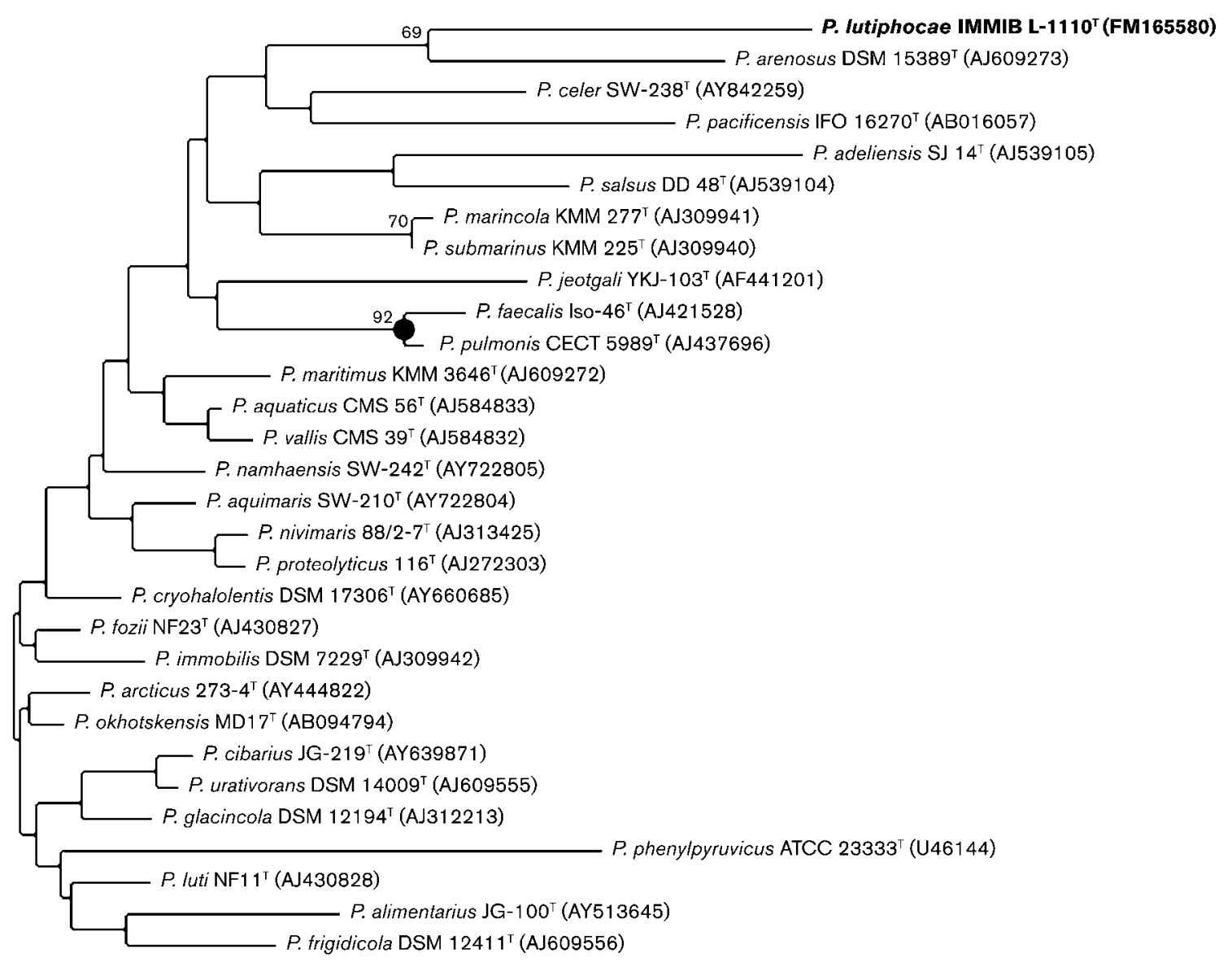

$5.0 \%$

Fig. 1. Neighbour-joining tree based on 16S rRNA gene sequences and showing the phylogenetic position of strain IMMIB $\mathrm{L}-1110^{\top}$ within the radiation of species in the genus Psychrobacter. Percentages $(>50 \%)$ at nodes are levels of bootstrap support based on 1000 resamplings. The solid circle indicates that the node was also recovered in maximum-likelihood and maximum-parsimony trees. Bar, $5.0 \%$ sequence divergence. 


\section{Description of Psychrobacter lutiphocae sp. nov.}

Psychrobacter lutiphocae (lu.ti.phoc'ae. L. n. lutum faeces; L. n. phoca a seal; N.L. gen. n. lutiphocae of faeces of a seal).

Cells are Gram-negative-staining, non-spore-forming, non-motile, diploid coccobacilli. Aerobic. Oxidase- and catalase-positive. Ubiquinone Q-8 is the major isoprenoid quinone. Spermidine is the predominant polyamine. The polar lipid profile is characterized by the presence of phosphatidylethanolamine, phosphatidylglycerol and diphosphatidylglycerol. The fatty acids $\mathrm{C}_{18: 1} \omega 9 c$ and $\mathrm{C}_{16: 1} \omega 7 c$ are the major non-hydroxylated fatty acids. The major hydroxylated fatty acid is $\mathrm{C}_{12: 0} 3-\mathrm{OH}$. Growth occurs with $0-6 \%(\mathrm{w} / \mathrm{v}) \mathrm{NaCl}$. Grows at 10 and $37^{\circ} \mathrm{C}$, but not at $42{ }^{\circ} \mathrm{C}$. Grows on MacConkey agar after 1 week at $37^{\circ} \mathrm{C}$. On Columbia agar, colonies are non-pigmented, circular, smooth and opaque with a diameter of 2-4 mm. Malate is assimilated but adipic acid, L-arabinose, capric acid, trisodium citrate, $\mathrm{N}$-acetylglucosamine, D-glucose, maltose, phenylacetic acid, potassium gluconate, D-mannose and D-mannitol are not assimilated. Acid is not produced from L-arabinose, glycogen, D-glucose, inulin, lactose, maltose, D-mannitol, raffinose, D-ribose, D-sorbitol, starch, sucrose, trehalose or D-xylose. Hippurate is hydrolysed, but aesculin, adenine, casein, elastin, gelatin, guanine, hypoxanthine, testosterone, tyrosine and xanthine are not hydrolysed. Activity is detected for ester lipase (C8), leucine arylamidase, naphthol-AS-BI-phosphohydrolase and urease. No activity is detected for acid phosphatase, alkaline phosphatase, arginine dihydrolase, chymotrypsin, cysteine arylamidase, esterase (C4), $\alpha$ fucosidase, $\alpha$ - and $\beta$-galactosidase, $\beta$-glucuronidase, $\alpha$ and $\beta$-glucosidase, $N$-acetyl- $\beta$-glucosaminidase, lipase (C14), $\alpha$-mannosidase, pyrazinamidase, pyrrolidonyl arylamidase, trypsin or valine arylamidase. Nitrate is reduced. Indole and acetoin production are negative.

The type strain, IMMIB L- $1110^{\mathrm{T}}\left(=\mathrm{DSM} 21542^{\mathrm{T}}=\mathrm{CCUG}\right.$ $56590^{\mathrm{T}}$ ), was isolated from the faeces of a seal.

\section{Acknowledgements}

We thank Professor Dr Hans-Georg Trüper for nomenclatural advice.

\section{References}

Bakermans, C., Ayala-del-Río, H. L., Ponder, M. A., Vishnivetskaya, T., Gilichinsky, D., Thomashow, M. F. \& Tiedje, J. M. (2006). Psychrobacter cryohalolentis sp. nov. and Psychrobacter arcticus sp. nov., isolated from Siberian permafrost. Int J Syst Evol Microbiol 56, 1285-1291.

Bowman, J. P., Austin, J. J., Cavanagh, J. \& Sanderson, K. (1996). Novel species of Psychrobacter from Antarctic ornithogenic soils. Int $J$ Syst Bacteriol 46, 841-848.

Bowman, J. P., Nichols, D. S. \& McMeekin, T. A. (1997). Psychrobacter glacincola sp. nov., a halotolerant, psychrophilic bacterium isolated from Antarctic sea ice. Syst Appl Microbiol 20, 209-215.

Bozal, N., Montes, J., Tudela, E. \& Guinea, J. (2003). Characterization of several Psychrobacter strains isolated from Antarctic environments and description of Psychrobacter luti sp. nov. and Psychrobacter fozii sp. nov. Int J Syst Evol Microbiol 53, 1093-1100.

Busse, H.-J. \& Auling, G. (1988). Polyamine pattern as a chemotaxonomic marker within the Proteobacteria. Syst Appl Microbiol 11, 1-8.

Collins, M. D., Pirouz, T., Goodfellow, M. \& Minnikin, D. E. (1977). Distribution of menaquinones in actinomycetes and corynebacteria. J Gen Microbiol 100, 221-230.

Denner, E. B. M., Mark, B., Busse, H.-J., Turkiewicz, M. \& Lubitz, W. (2001). Psychrobacter proteolyticus sp. nov., a psychrotrophic, halotolerant bacterium isolated from the Antarctic krill Euphausia superba Dana, excreting a cold-adapted metalloprotease. Syst Appl Microbiol 24, 44-53.

Felsenstein, J. (1981). Evolutionary trees from DNA sequences: a maximum likelihood approach. J Mol Evol 17, 368-376.

Felsenstein, J. (1985). Confidence limits on phylogenies: an approach using the bootstrap. Evolution 39, 783-791.

Fitch, W. M. (1971). Toward defining the course of evolution: minimum change for a specific tree topology. Syst Zool 20, 406-416.

Gordon, R. E. (1966). Some criteria for the recognition of Nocardia madurae (Vincent) Blanchard. J Gen Microbiol 45, 355-364.

Gordon, R. E. (1967). The taxonomy of soil bacteria. In The Ecology of Soil Bacteria, pp. 293-321. Edited by T. R. G. Gray \& B. Parkinson. Liverpool: University Press.

Gordon, R. E. \& Mihm, J. M. (1957). A comparative study of some strains received as nocardiae. J Bacteriol 73, 15-27.

Hamana, K., Sato, W., Gouma, K., Yu, J., Ino, Y., Umemura, Y., Mochizuki, C., Takatsuka, K., Kigure, Y. \& other authors (2007). Cellular polyamine catalogues of the five classes of the phylum Proteobacteria: distributions of homospermidine within the class Alphaproteobacteria, hydroxyputrescine within the class Betaproteobacteria, norspermidine within the class Gammaproteobacteria, and spermidine within the classes Deltaproteobacteria and Epsilonproteobacteria. Ann Gunma Health Sci 27, 1-16.

Heuchert, A., Glöckner, F. O., Amann, R. \& Fischer, U. (2004). Psychrobacter nivimaris sp. nov., a heterotrophic bacterium attached to organic particles isolated from the South Atlantic (Antarctica). Syst Appl Microbiol 27, 399-406.

Jung, S.-Y., Lee, M.-H., Oh, T.-K., Park, Y.-H. \& Yoon, J.-H. (2005). Psychrobacter cibarius sp. nov., isolated from jeotgal, a traditional Korean fermented seafood. Int J Syst Evol Microbiol 55, 577-582.

Juni, E. \& Heym, G. A. (1986). Psychrobacter immobilis gen. nov., sp. nov.: genospecies composed of Gram-negative, aerobic, oxidasepositive coccobacilli. Int J Syst Bacteriol 36, 388-391.

Kämpfer, P., Albrecht, A., Buczolits, S. \& Busse, H.-J. (2002). Psychrobacter faecalis sp. nov., a new species from a bioaerosol originating from pigeon faeces. Syst Appl Microbiol 25, 31-36.

Ludwig, W., Strunk, O., Westram, R., Richter, L., Meier, H., Yadhukumar, Buchner, A., Lai, T., Steppi, S. \& other authors (2004). ARB: a software environment for sequence data. Nucleic Acids Res 32, 1363-1371.

Maruyama, A., Honda, D., Yamamoto, K., Kitamura, K. \& Higashihara, T. (2000). Phylogenetic analysis of psychrophilic bacteria isolated from the Japan Trench, including a description of the deep-sea species Psychrobacter pacificensis sp. nov. Int J Syst Evol Microbiol 50, 835-846.

Rainey, F. A., Ward-Rainey, N., Kroppenstedt, R. M. \& Stackebrandt, E. (1996). The genus Nocardiopsis represents a phylogenetically coherent taxon and a distinct actinomycete lineage: proposal of Nocardiopsaceae fam. nov. Int J Syst Bacteriol 46, 1088-1092. 
Romanenko, L. A., Schumann, P., Rohde, M., Lysenko, A. M., Mikhailov, V. V. \& Stackebrandt, E. (2002). Psychrobacter submarinus sp. nov. and Psychrobacter marincola sp. nov., psychrophilic halophiles from marine environments. Int J Syst Evol Microbiol 52, 1291-1297.

Romanenko, L. A., Lysenko, A. M., Rohde, M., Mikhailov, V. V. \& Stackebrandt, E. (2004). Psychrobacter maritimus sp. nov. and Psychrobacter arenosus sp. nov., isolated from coastal sea ice and sediments of the Sea of Japan. Int J Syst Evol Microbiol 54, 1741-1745.

Saitou, N. \& Nei, M. (1987). The neighbor-joining method: a new method for reconstructing phylogenetic trees. Mol Biol Evol 4, 406425.

Shivaji, S., Reddy, G. S. N., Suresh, K., Gupta, P., Chintalapati, S., Schumann, P., Stackebrandt, E. \& Matsumoto, G. I. (2005). Psychrobacter vallis sp. nov. and Psychrobacter aquaticus sp. nov., from Antarctica. Int J Syst Evol Microbiol 55, 757-762.

Stackebrandt, E. \& Goebel, B. M. (1994). Taxonomic note: a place for DNA-DNA reassociation and $16 \mathrm{~S}$ rRNA sequence analysis in the present species definition in bacteriology. Int J Syst Bacteriol 44, 846-849.

Stolz, A., Busse, H.-J. \& Kämpfer, P. (2007). Pseudomonas knackmussii sp. nov. Int J Syst Evol Microbiol 57, 572-576.

Vela, A. I., Collins, M. D., Latre, M. V., Mateos, A., Moreno, M. A., Hutson, R., Dominguez, L. \& Fernandez-Garayzabal, J. F. (2003).
Psychrobacter pulmonis sp. nov., isolated from the lungs of lambs. Int $J$ Syst Evol Microbiol 53, 415-419.

Yassin, A. F. \& Hupfer, H. (2006). Williamsia deligens sp. nov., isolated from human blood. Int J Syst Evol Microbiol 56, 193-197.

Yassin, A. F., Haggenei, B., Budzikiewicz, H. \& Schaal, K. P. (1993). Fatty acid and polar lipid composition of the genus Amycolatopsis: application of fast atom bombardment-mass spectrometry to structure analysis of underivatized phospholipids. Int J Syst Bacteriol 43, 414-420.

Yassin, A. F., Chen, W. M., Hupfer, H., Siering, C., Kroppenstedt, R. M., Arun, A. B., Lai, W. A., Shen, F. T., Rekha, P. D. \& Young, C. C. (2007). Lysobacter defluvii sp. nov., isolated from municipal solid waste. Int J Syst Evol Microbiol 57, 1131-1136.

Yoon, J.-H., Kang, K. H. \& Park, Y.-H. (2003). Psychrobacter jeotgali sp. nov., isolated from jeotgal, a traditional Korean fermented seafood. Int J Syst Evol Microbiol 53, 449-454.

Yoon, J. H., Lee, C. H., Kang, S. J. \& Oh, T. K. (2005a). Psychrobacter celer sp. nov., isolated from sea water of the South Sea in Korea. Int $J$ Syst Evol Microbiol 55, 1885-1890.

Yoon, J.-H., Lee, C.-H., Yeo, S.-H. \& Oh, T.-K. (2005b). Psychrobacter aquimaris sp. nov. and Psychrobacter namhaensis sp. nov., isolated from sea water of the South Sea in Korea. Int J Syst Evol Microbiol 55, 1007-1013. 